\title{
Anti-inflammatory/anti-fibrotic effects of the hepatoprotective silymarin and the schistosomicide praziquantel against Schistosoma mansoni-induced liver fibrosis
}

Naglaa M El-Lakkany ${ }^{1 *}$, Olfat A Hammam², Walaa H El-Maadawy ${ }^{1}$, Afkar A Badawy², Afaf A Ain-Shoka ${ }^{3}$ and Fatma A Ebeid ${ }^{1}$

\begin{abstract}
Background: Praziquantel (PZQ) is an isoquinoline derivative (2-cyclohexylcarbonyl-1, 2, 3, 6, 7, 11 b-hexahydro-4Hpyrazino\{2,1-a\}-isoquinoline-4-one), and is currently the drug of choice for all forms of schistosomiasis. Silymarin, a standardized milk thistle extract, of which silibinin is the main component, is known for its hepatoprotective, antiinflammatory, antioxidant activities, and hepatocyte regeneration. This study investigates the anti-inflammatory/antifibrotic effects of silymarin and/or PZQ on schistosomal hepatic fibrosis.

Methods: Schistosoma mansoni-infected mice were divided into two large groups (I \& II), each with four subgroups and were run in parallel. (i) Infected untreated; (ii) treated with silymarin, starting from the $4^{\text {th }}$ ( 3 weeks before PZQ therapy) or $12^{\text {th }}$ (5 weeks after PZQ therapy) weeks post infection (PI); (iii) treated with PZQ in the $7^{\text {th }}$ week Pl; and (iv) treated with silymarin, as group (ii) plus PZQ as group (iii). Comparable groups of uninfected mice run in parallel with the infected groups. Mice of groups I and II were killed 10 and 18 weeks PI, respectively. Hepatic content of hydroxyproline (HYP), serum levels and tissue expression of matrix metalloproteinase-2 (MMP-2), transforming growth factor- $\beta 1$ (TGF- $\beta$ 1) and number of mast cells were determined. In addition, parasitological, biochemical and histological parameters that reflect disease severity and morbidity were examined.

Results: Silymarin caused a partial decrease in worm burden; hepatic tissue egg load, with an increase in percentage of dead eggs; modulation of granuloma size, with significant reduction of hepatic HYP content; tissue expression of MMP-2, TGF- $\beta 1$; number of mast cells, with conservation of hepatic reduced glutathione (GSH). PZQ produced complete eradication of worms, eggs and alleviated liver inflammation and fibrosis. The best results were obtained, in most parameters studied, in groups of mice treated with silymarin in addition to PZQ.

Conclusions: Our results point to silymarin as a promising anti-inflammatory and anti-fibrotic agent; it could be introduced as a therapeutic tool with PZQ in the treatment of schistosomal liver fibrosis, but further studies on mechanisms of silymarin and PZQ in chronic liver diseases may shed light on developing therapeutic methods in clinical practice.
\end{abstract}

Keywords: Schistosoma mansoni, silymarin, praziquantel, liver fibrosis, hydroxyproline, transforming growth factor$\beta 1$, matrix metalloproteinase-2, mast cells

\footnotetext{
* Correspondence: naglaaellakkany@yahoo.com

'Department of Pharmacology, Theodor Bilharz Research Institute, Warrak El-

Hadar, Imbaba, P.O Box 30, Giza 12411, Egypt

Full list of author information is available at the end of the article
} 


\section{Background}

Schistosomiasis caused by S. mansoni continues to be an important cause of parasitic morbidity and mortality worldwide and is the most common fibrotic disease to arise due to inflammation and the deposition of scar tissue around parasite eggs trapped in the liver [1]. It is usually characterized by an unnoticed acute phase, followed by liver fibrosis at chronic and advanced stages [2]. In fibrosis, an excessive deposition of extracellular matrix (ECM) components is observed, such as type III collagen in the fibrotic process, and types I and II collagen, fibronectin and proteoglycan at various stages of granuloma formation [3]. The activated hepatic stellate cells (HSCs) have now been identified as the primary source of extracellular matrix synthesis in liver fibrogenesis [4]. Fibrogenic cytokines, like transforming growth factor- $\beta$ (TGF- $\beta$ ) are among the major cytokines involved in the activation process, causing enhanced proliferation of HSCs and matrix synthesis [5]. Mast cell hyperplasia in the liver has also been observed in a variety of experimental models of rat-liver fibrosis, such as that induced by $\mathrm{CCl}_{4}$, diethylnitrosamine, radiation, porcine serum, and bile duct resection [6]. Mast cells, which are derived from hematopoietic progenitors, leave the bone marrow and migrate to areas of inflammation. TGF- $\beta 1$ is the most potent mast cell chemo-attractant and is responsible for this directional migration at femtomolar (fM) concentrations, and tissue maturation of mast cells [7]. Thus, the activation of mast cells and the subsequent exocytosis of granules are followed by production and secretion of cytokines and other factors that lead to leukocyte infiltration and local inflammation [8]. Matrix metalloproteinases (MMPs) are the major enzymes that degrade the various types of collagen. In the liver, MMP-2 is produced abundantly by the activated HSCs and fibroblasts, although other resident liver cells may be minor producers of MMP-2

[9]. It is well known that fibrosis is reversible whereas cirrhosis is irreversible, so it is important to prevent fibrosis progressing to cirrhosis. However, there is no ideal anti-fibrotic drug to date. Available therapies for many chronic liver diseases are ineffective, with liver transplantation as the only option. Novel approaches that attack the scarring response are therefore urgently needed [10]. Praziquantel (PZQ), as a safe anti-schistosome drug, has been used for more than 30 years [11]. In general, specific treatment of schistosomiasis results in parasite elimination, and later on, a slight reduction in hepatic fibrosis that is attributed to parasite eradication [12]. Silymarin, a standardized extract of the milk thistle (Silybum marianum [L.] Gaertner) has a long tradition as an herbal remedy; it was introduced as a "hepatoprotective" agent more than 30 years ago and used clinically in Europe and Asia for the treatment of liver diseases $[13,14]$. Silymarin consists of four flavonolignan isomers namely: silybin (also known as silybinin or silibinin), isosilybin, silydianin and silychristin [13]. Silybin is the most prevalent and biologically active of the four isomers and represents about $60-70 \%$ of silymarin, followed by silychristin (20\%), silidianin (10\%), and isosilybin (5\%). Silymarin offers good protection in various toxic models of experimental liver diseases in laboratory animals. The protective action of silymarin is explicable in terms of its capacity for trapping free radicals and has a stabilizing effect on the cytoplasmic membranes. It promotes protein synthesis, helps in regenerating liver tissue, enhances glucuronidation and protects against glutathione depletion. Moreover, it is a potent anti-inflammatory, immunomodulatory and antifibrogenic agent in the liver $[8,15]$. In a recent study by Mata-Santos, et al. [16] on the effect of silymarin treatment in experimental schistosomiasis, silymarin did not affect parasite oviposition capacity; reduced granulomatous peri-ovular reaction in the liver, and decreased hepatic fibrosis in this infection. Since research into the effect of silymarin on schistosomal hepatic fibrosis is very limited, we are interested to test its anti-inflammatory/anti-fibrotic effects alone and with the anti-schistosomal PZQ, on acute and chronic schistosomal liver fibrosis. Parasitological criteria, function and histopathology of the liver, serum and tissue markers of liver fibrosis were also examined.

\section{Methods}

\section{Drugs and dosage}

Silymarin $\left(\right.$ Legalon $^{\circledR}$ ) purchased from (Chemical Industries Development (CID), Giza, Egypt under License of: Madaus $\mathrm{GmbH}$. Germany) was given orally in a dose of $750 \mathrm{mg} / \mathrm{kg} /$ day [17], 5 days/week for 6 weeks in the form of aqueous suspension in 2\% Cremophor El (Sigma Chemical Co., St. Louis, MO, USA). Praziquantel $^{\circledR}$ (Praziquantel-Sedico Pharmaceutical Co. $6^{\text {th }}$ of October City, Egypt) was given orally in a total dose of $1000 \mathrm{mg} / \mathrm{kg}$ divided equally on two consecutive days [18] in the form of aqueous suspension in $2 \%$ Cremophor El.

\section{Animals}

Eighty CD-1 Swiss male albino mice, weighing 18-20 g were provided by the Schistosome Biology Supply Center (SBSC) of the Theodor Bilharz Research Institute (TBRI), Giza, Egypt. The mice were maintained on a standard commercial pelleted diet (El-Kahira company for oils and soap) in an air-conditioned animal house at 20-22 $\mathrm{C}$. The animal experiments were conducted at the TBRI animal unit in accordance with international, 
ethical guidelines after approval of the institutional ethical committee of TBRI.

\section{Infection of animals}

Animals were infected with the Egyptian strain of $S$. mansoni (70 \pm 5 cercariae/mouse) using the body immersion technique according to the method described by Liang et al. [19].

\section{Experimental design}

Experiment I (acute infection): S. mansoni-infected mice were divided into 4 groups, Group (i) infected mice received the vehicle (2\% Cremophor $\mathrm{El}$ ), Group (ii) treated with silymarin starting from the $4^{\text {th }}$ week (3 weeks before PZQ therapy) to the $10^{\text {th }}$ week PI. Group (iii) treated with PZQ in the $7^{\text {th }}$ week PI and Group (iv) treated with both silymarin and PZQ at the same time intervals as described in Groups (ii) and (iii).

Experiment II (chronic infection): S. mansoni-infected mice were divided into 4 groups, Group (i) infected mice received the vehicle (2\% Cremophor El), Group (ii) treated with silymarin starting from the $12^{\text {th }}$ week (5 weeks after PZQ therapy) to the $18^{\text {th }}$ week PI. Group (iii) treated with PZQ in the $7^{\text {th }}$ week PI and Group (iv) treated with both silymarin and PZQ at the same time intervals as described in Groups (ii) and (iii). Animals of experiments I and II were killed by decapitation 10 and 18 weeks PI, respectively. Comparable groups of uninfected mice received the vehicle (2\% Cremophor El) and were run in parallel with the infected groups and killed at a time corresponding to 10 and 18 weeks PI, respectively.

After decapitation, blood was collected and sera were separated by centrifugation at $1850 \mathrm{~g}$ for 10 minutes and stored frozen at $-70^{\circ} \mathrm{C}$ prior to the pending assay. The livers were immediately chilled on ice and a piece of $0.5 \mathrm{~g}$ was homogenized using a Potter glass homogenizer equipped with a teflon pestle in 2.5 volumes $(\mathrm{w} / \mathrm{v})$ ice cold $0.1 \mathrm{M}$ potassium phosphate buffer adjusted to $\mathrm{pH}$ 6.5. The crude homogenate was then centrifuged at $10.000 \mathrm{~g}$ for one hour at $4{ }^{\circ} \mathrm{C}$ and the supernatant was harvested and snap frozen at $-80^{\circ} \mathrm{C}$ in Eppendorf vials for subsequent analysis of the hepatic content of reduced glutathione (GSH). Another gram of liver was homogenized in 5 volumes $(\mathrm{w} / \mathrm{v})$ of $0.9 \%$ cold normal saline $(0.9 \% \mathrm{NaCl})$. The crude homogenate was harvested and stored frozen at $-70^{\circ} \mathrm{C}$ in Eppendorf vials for subsequent analysis of the hepatic content of HYP.

\section{Assessment of parasitological criteria}

Hepatic and portomesenteric vessels were perfused [20] to recover worms for subsequent counting. The number of ova per gram of liver or intestine tissues was counted
[21]. Percentage of the different egg developmental stages (oogram pattern) was examined [22].

\section{Histopathology and granuloma measurement}

Livers recovered from mice were fixed in $10 \%$ buffered formalin and processed to paraffin blocks. Sections (4 $\mu \mathrm{m}$ thick) were cut $250 \mu \mathrm{m}$ away from the preceding sections to avoid measurement of the same granuloma. Five paraffin liver sections were prepared from each animal and stained with haematoxylin and eosin (H\&E) and Masson trichrome stains. Measurements of the granuloma size were conducted on non-contiguous granulomas, each containing a single egg (with intact or degenerated miracidia), using an ocular micrometer. The mean diameter of each granuloma was calculated by measuring two diameters of the lesion at right angles to each other [23]. For each mouse, 40 granulomas were measured and associated hepatic histopathological changes were studied.

\section{Liver function tests}

Concentrations of alanine aminotransferase (ALT) and albumin in the collected sera were estimated using the available commercial kits (Sentinel $\mathrm{CH}$, Milan, Italy). The level of reduced glutathione was determined in liver homogenate according to the method described by Ellman [24]. Briefly, $0.5 \mathrm{ml}$ homogenate was added to a tube with $0.5 \mathrm{ml}$ of $10 \%$ trichloroacetic acid. The tubes were centrifugated at $3000 \mathrm{~g}$ for $10 \mathrm{~min}$. A $0.2 \mathrm{ml}$ aliquot of the resulting supernatant was added to a tube containing $5 \mathrm{ml}$ of $0.1 \mathrm{M}$ phosphate buffer and $0.1 \mathrm{ml}$ of 5, 5'-dithio-bis-(2-nitro benzoic acid; DTNB) solution (Ellman's reagent) and the absorbance was measured at $412 \mathrm{~nm}$. A standard graph was drawn using different concentrations of a standard GSH solution $(1 \mathrm{mg} / \mathrm{ml})$. With the help of the standard graph, the GSH contents in the liver homogenates of the experimental animals were calculated.

\section{Liver fibrosis markers}

As an index of liver fibrosis, (a) hydroxyproline was estimated in the liver using the method of Woessner [25]. Briefly, $0.5 \mathrm{ml}$ of $20 \%$ liver homogenate was digested in $1 \mathrm{ml}$ of $6 \mathrm{~mol} / \mathrm{L} \mathrm{HCl}$ at $120^{\circ} \mathrm{C}$ for 8 hours. An aliquot of digested homogenate $(25 \mathrm{ml})$ was added to $25 \mathrm{ml}$ citrate-acetate buffer and finally $500 \mathrm{ml}$ of chloraminesT-solution was added and the mixture was left at room temperature for $20 \mathrm{~min}$. Then, $500 \mathrm{ml}$ Ehrlich's solution was added and the mixture was incubated at $65^{\circ} \mathrm{C}$ for 15 minutes. After cooling for 10 minutes, the color that developed was measured spectrophotometrically at 550 $\mathrm{nm}$. (b) serum matrix metalloproteinases type-2 (MMP2) determined using an ELISA kit (Quantikine R\&D 
Systems, Minneapolis, Minnesota, USA) and (c) serum transforming growth factor $\beta 1$ (TGF- $\beta 1$ ) was determined using an ELISA kit (IBL International, $\mathrm{GmbH}$, Hamburg, Germany).

\section{Immunohistochemical procedure}

The standard avidin-biotin immunoperoxidase technique was used [26]. Paraffin sections (5 $\mu$ m thick) were cut on positively charged slides, dewaxed in xylene and hydrated in descending grades of ethanol. The endogenous peroxidase activity was quenched by incubation in $100 \%$ methanol with $3 \%$ hydrogen peroxide for 20 minutes. Antigen retrieval was performed by subjecting the sections, in citrate buffer ( $\mathrm{pH} 7.0$ ), to 15 minutes of microwaves at $700 \mathrm{~W}$. Sections were incubated overnight at $+4^{\circ} \mathrm{C}$ in a humid chamber with primary antimouse monoclonal antibodies against TGF- $\beta 1$ and MMP-2 (Santa Cruz Biotechnology, California, USA). The antibodies were diluted 1:50 and 1:100 respectively, in phosphate buffer saline (PBS). After rinsing in PBS, the sections were incubated at room temperature for 15 minutes with biotinylated secondary anti-mouse antibody and after a further wash in PBS, the slides were incubated with an avidin-biotin complex horseradish peroxidase solution (DAKO, Glostrup, Denmark). After 10 minutes of incubation, the peroxidase reaction was developed using $0.01 \%$ hydrogen peroxide in $0.05 \%$ diaminobenzidine tetrahydrochloride (DAB). Sections were counterstained with Meyer's hematoxylin and dehydrated in ethanol prior to mounting. Liver sections with the primary antibody replaced with PBS, served as negative controls, while colonic cancer sections served as TGF- $\beta 1$ and MMP-2-positive controls.

The liver sections were examined using a Zeiss light microscope (Oberkochen, Germany). The number of positively stained cells with the highest expression recorded within 10 successive fields $(x 400)$ was counted per section animal in a semi-quantitative way for both markers; the final value represented the mean of 80 readings per group. Zero percentage was given to unstained sections. TGF- $\beta 1$ expression sites were examined intralobularly, in the periportal areas, in hepatocytes, and granuloma [27]. MMP-2 expression sites were examined in hepatocytes, Kupffer cells and endothelial cells lining sinusoids and granuloma [28].

\section{Number of mast cells in liver tissue}

Toluidine blue staining for mast cells was performed by immersion of liver sections in $0.1 \%$ toluidine blue (Sigma, USA) for 3-5 minutes at room temperature [29]. Both intact and degranulated mast cells as well as the total number of mast cells was quantified in 10 successive selected, non-overlapping, high power fields $(x 400)$ of each liver section [30].

\section{Statistical analysis}

Data was analysed using version 11.0 of the SPSS software package (SPSS Inc., Chicago, IL, USA), with the results expressed as means with standard errors. Group means were compared using unpaired Student's $t$-tests. A $P$-value of $<0.05$ was considered indicative of a statistically significant difference.

\section{Results}

\section{Parasitological studies}

Treatment of infected mice with silymarin for 6 weeks starting from the $4^{\text {th }}$ and $12^{\text {th }}$ weeks PI resulted in a reduction in the total worm burden; recovered 10 and 18 weeks PI by $26.25 \%(P>0.05)$ and $39.39 \%(P<0.001)$ respectively when compared to the infected untreated group. Moreover, a significant reduction $(P<0.01)$ in the hepatic tissue egg load by $28.73 \%$ and $43.13 \%$, accompanied with significant increase $(P<0.05, P<0.01)$ in the percentage of dead eggs was observed 10 and 18 weeks PI, respectively. Administration of PZQ alone or with silymarin resulted in $97-100 \%$ worm and egg eradication with $~ 77 \%$ reduction in the hepatic tissue egg load with no significant difference recorded between the two groups (Table 1).

\section{Histopathological changes}

Ten weeks post infection; the inflammatory granulomatous lesions were mainly seen in the hepatic parenchyma and to a lesser extent in the portal tracts. Fibrocellular granulomas, constituted around $60 \%$ of the estimated granulomas with mean granuloma diameter $403.83 \pm 15.76 \mu \mathrm{m}$. In the chronic stage of $S$. mansoni infection (18 weeks PI) with immune modulation, fibrocellular granulomas (around $80 \%$ of the estimated granuloma) had fewer inflammatory cells and more fibrous tissue content with mean diameter of $349.50 \pm 4.50 \mu \mathrm{m}$. With the progression of infection, the portal tracts were more expanded by the amalgamated granulomatous lesions that had developed around the newly deposited ova with subsequent collagen deposition along portal tracts. Treatment with PZQ reduced both the granuloma size and inflammatory cells 10 and 18 weeks PI. In addition, administration of silymarin to infected mice resulted in the regression of the granulomatous inflammatory reaction with significant reduction in granuloma size, 10 and 18 weeks PI when compared with their corresponding infected untreated groups. Administration of PZQ with silymarin resulted in a marked decrease in inflammatory cells in portal tracts and granulomas, with significant reduction in granuloma size $(P<0.05, P<0.001), 10$ and 18 weeks PI respectively, when compared to their corresponding PZQ treated groups (Figure 1).

\section{Liver function assessments}

Infection of mice with $S$. mansoni showed a significant increase in serum levels of ALT $(P<0.01, P<0.001)$ 
Table 1 Effect of silymarin with/without praziquantel on total worms, hepatic tissue egg load and \% dead eggs 10 and 18 weeks post infection of mice with S.mansoni

\begin{tabular}{|c|c|c|c|c|c|c|}
\hline \multirow[t]{2}{*}{ Animal groups } & \multicolumn{2}{|c|}{ Total worms } & \multicolumn{2}{|c|}{ Hepatic tissue egg load $\times 10^{3}$} & \multicolumn{2}{|c|}{$\%$ dead eggs } \\
\hline & 10 wks & 18 wks & 10 wks & 18 wks & 10 wks & 18 wks \\
\hline Infected (Vehicle) & $19.16 \pm 2.18$ & $20.28 \pm 0.99$ & $16.22 \pm 1.40$ & $27.08 \pm 3.53$ & $7.16 \pm 0.94$ & $6.87 \pm 0.99$ \\
\hline Infected + PZQ & 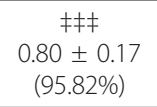 & $\begin{array}{c}\text { 㧊 } \\
0.50 \pm 0.27 \\
(97.53 \%)\end{array}$ & 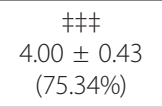 & $\begin{array}{c}\text { 㧊 } \\
7.64 \pm 1.10 \\
(71.79 \%)\end{array}$ & 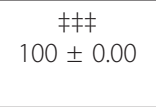 & $\begin{array}{c}\text { 抹 } \\
100 \pm 0.00\end{array}$ \\
\hline Infected + silymarin & $\begin{array}{c}14.13 \pm 2.96 \\
(26.25 \%)\end{array}$ & $\begin{array}{c}\text { 抹 } \\
12.29 \pm 1.21 \\
(39.39 \%)\end{array}$ & $\begin{array}{c}\text { 护 } \\
11.56 \pm 0.68 \\
(28.73 \%)\end{array}$ & $\begin{array}{c}\neq \neq \\
15.40 \pm 0.72 \\
(43.13 \%)\end{array}$ & $\begin{array}{c}\neq \\
11.00 \pm 0.97\end{array}$ & 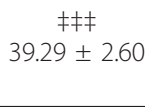 \\
\hline Infected + PZQ + silymarin & 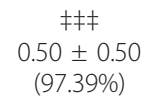 & 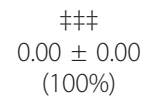 & 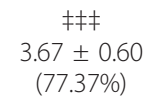 & 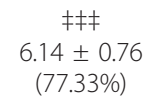 & 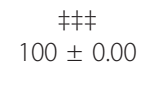 & $\begin{array}{c}\text { 㧊 } \\
100 \pm 0.00\end{array}$ \\
\hline
\end{tabular}

Data are presented as mean \pm SEM ( $\mathrm{n}=8$ in each group).

Mice were administered praziquantel (PZQ; $500 \mathrm{mg} / \mathrm{kg} /$ day for 2 days) in the $7^{\text {th }}$ week post infection (PI) and silymarin (750 mg/kg/day, 5 days/week for 6 weeks) at the $4^{\text {th }}$ and $12^{\text {th }}$ weeks PI for 6 weeks and were killed 10 and 18 weeks PI respectively. Numbers in parentheses indicate the percentage of reduction from infected (vehicle) group.

‡ Significantly different from infected (vehicle) group at $P<0.05$, $\neq \neq>0.01$ and $\neq \neq \neq$ at $P<0.001$.

with a significant decrease in both albumin $(P<0.01) 18$ weeks PI, and hepatic GSH $(P<0.001) 10$ and 18 weeks $\mathrm{PI}$ in comparison with the uninfected untreated group. Compared to the infected untreated group, ALT level was significantly decreased in the group treated with either PZQ $(P<0.05, P<0.01))$ or silymarin $(P<0.05$; 18 weeks $P I)$ alone or with both $\operatorname{drugs}(P<0.01, P<$
0.001) 10 and 18 weeks PI, respectively. Moreover, serum albumin was significantly elevated in groups treated with either PZQ alone $(P<0.01)$ or combined with silymarin $(P<0.05) 18$ weeks PI. In addition to that, the hepatic GSH was significantly elevated in groups treated with PZQ alone $(P<0.05, P<0.001)$, silymarin alone $(P$ $<0.01)$ or both $(P<0.01, P<0.001), 10$ and 18 weeks

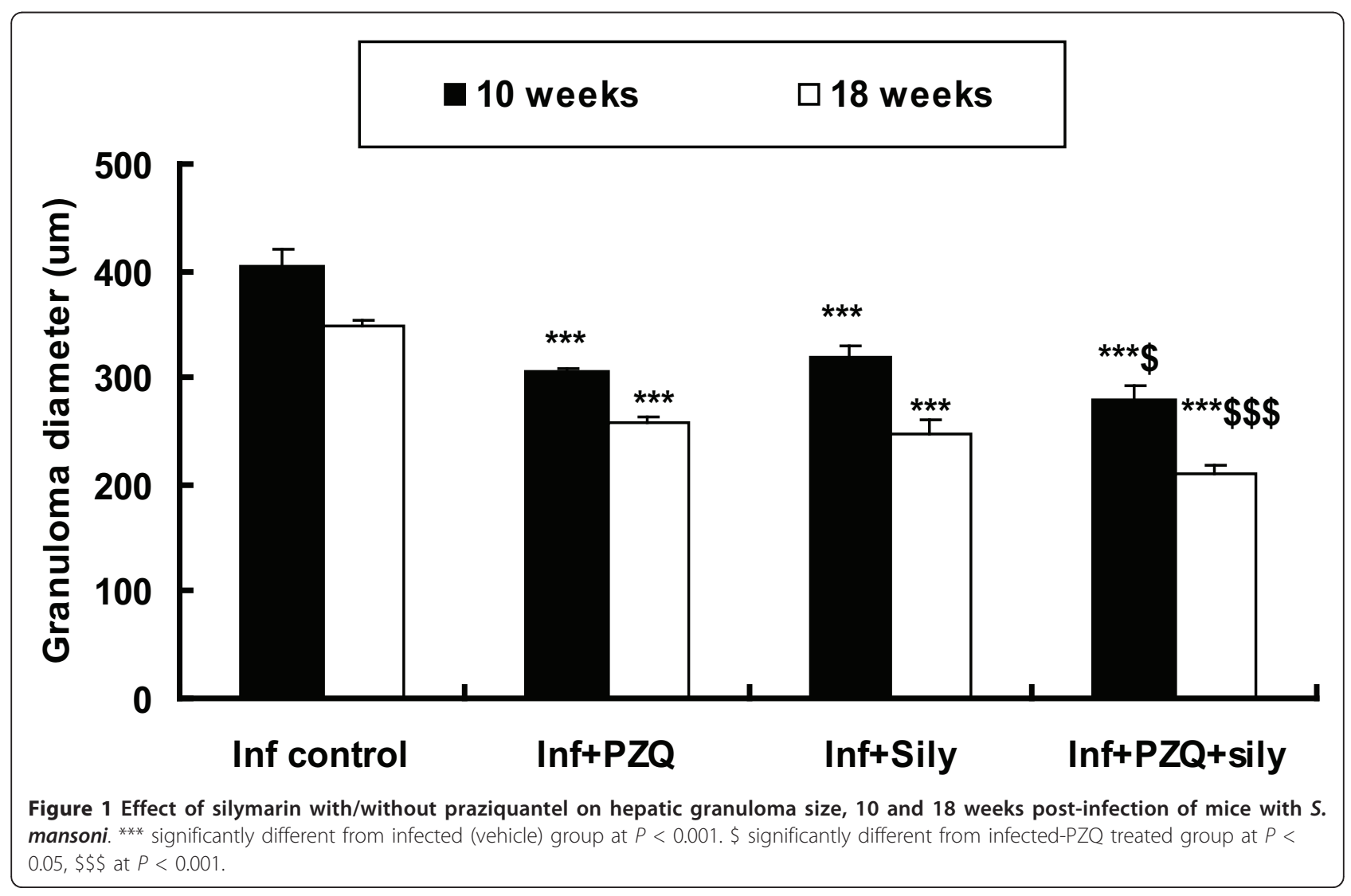


Table 2 Effect of silymarin with/without praziquantel on liver function tests, 10 and 18 weeks post-infection of mice with S.mansoni

\begin{tabular}{|c|c|c|c|c|c|c|}
\hline \multirow[t]{2}{*}{ Animal groups } & \multicolumn{2}{|c|}{$\begin{array}{c}\text { Serum ALT } \\
(U / L)\end{array}$} & \multicolumn{2}{|c|}{$\begin{array}{l}\text { Serum albumin } \\
(\mathrm{g} / \mathrm{dl})\end{array}$} & \multicolumn{2}{|c|}{$\begin{array}{l}\text { Hepatic GSH } \\
\text { (mg/g liver) }\end{array}$} \\
\hline & 10 wks & 18 wks & 10 wks & 18 wks & 10 wks & 18 wks \\
\hline Uninfected (vehicle) & $22.62 \pm 1.82$ & $21.67 \pm 0.93$ & $3.75 \pm 0.21$ & $3.55 \pm 0.23$ & $6.00 \pm 0.29$ & $5.92 \pm 0.26$ \\
\hline Infected (Vehicle) & $\begin{array}{c}\dagger+ \\
40.71 \pm 4.07\end{array}$ & $\begin{array}{c}\text { t+† } \\
32.57 \pm 1.94 \\
\end{array}$ & & $\begin{array}{c}\dagger+ \\
2.69 \pm 0.07 \\
\end{array}$ & $\begin{array}{c}\text { ††+ } \\
2.80 \pm 0.22\end{array}$ & $\begin{array}{c}\text { †十+ } \\
2.12 \pm 0.21\end{array}$ \\
\hline Infected + PZQ & $\begin{array}{c}\text { †† } \\
30.57 \pm 1.25\end{array}$ & $\begin{array}{c}\text { 㧊 } \\
23.17 \pm 1.76\end{array}$ & & $\begin{array}{c}\text { 㧊 } \\
3.08 \pm 0.07\end{array}$ & $\begin{array}{c}\text { †十キ } \\
3.40 \pm 0.13\end{array}$ & $\begin{array}{c}\text { †十キキキキ } \\
4.07 \pm 0.29\end{array}$ \\
\hline Infected + silymarin & $\begin{array}{c}\text { ††† } \\
39.75 \pm 3.57\end{array}$ & $\begin{array}{c}\neq \dagger \\
26.80 \pm 2.00\end{array}$ & & $\begin{array}{c}t \\
2.90 \pm 0.05\end{array}$ & $\begin{array}{c}\text { †十㧊 } \\
4.43 \pm 0.32\end{array}$ & $\begin{array}{c}\text { †††キキ } \\
3.18 \pm 0.22\end{array}$ \\
\hline Infected + PZQ + silymarin & $\begin{array}{c}\text { 护 } \\
25.88 \pm 1.41\end{array}$ & $\begin{array}{c}\text { 抹 } \\
19.75 \pm 1.56\end{array}$ & & $\begin{array}{c}\neq \\
3.17 \pm 0.19\end{array}$ & $\begin{array}{c}\neq \neq \S \S \\
5.90 \pm 0.68\end{array}$ & $\begin{array}{c}\dagger \neq \neq \neq \S \\
4.99 \pm 0.19\end{array}$ \\
\hline
\end{tabular}

Data are presented as mean \pm SEM ( $n=8$ in each group).

Mice were administered praziquantel (PZQ; $500 \mathrm{mg} / \mathrm{kg} /$ day for 2 days) in the $7^{\text {th }}$ week post infection (PI) and silymarin (750 mg/kg/day, 5 days/week for $6 \mathrm{weeks)}$ at the $4^{\text {th }}$ and $12^{\text {th }}$ weeks PI for 6 weeks and were killed 10 and 18 weeks PI respectively.

ALT, Alanine aminotransferase; GSH, reduced glutathione.

† Significantly different from uninfected (vehicle) group at $P<0.05$, †† at $P<0.01$ and $+\dagger \dagger$ at $P<0.001$. $\neq$ Significantly different from infected (vehicle) group at $P<0.05$, $\neq \neq$ at $P<0.01$ and $\neq \neq \neq$ at $P<0.001$. $\S$ Significantly different from infected treated with $\mathrm{PZQ}$ group at $P<0.05$ and $\S \S$ at $P<0.01$.

PI, respectively. Compared to the PZQ treated group, hepatic GSH was significantly restored in the group treated with both PZQ and silymarin $10(P<0.01)$ and $18(P<0.05)$ weeks PI (Table 2$)$.

\section{Liver fibrosis markers}

Infection of mice with $S$. mansoni caused pronounced elevations in both serum TGF- $\beta 1(P<0.001)$ and MMP-2 $(P$ $<0.01, P<0.001)$ levels, 10 and 18 weeks PI respectively, when compared to their corresponding uninfected untreated groups. Compared to the infected untreated group, treatment with PZQ caused a significant reduction in both serum TGF- $\beta 1(P<0.001)$ and MMP-2 $(P<0.05$, $P<0.001)$ levels by $(43.34 \%, 51.75 \%)$ and $(20.73 \%$, $39.35 \%), 10$ and 18 weeks PI, respectively. Treatment with silymarin resulted in a significant reduction of TGF- $\beta 1(P$ $<0.05)$ by $32.73 \% 10$ weeks PI with insignificant reductions $(P>0.05)$ in serum TGF- $\beta 1,18$ weeks PI and MMP2 levels 10 and18 weeks PI. Administration of PZQ in combination with silymarin caused normalization with significant reduction of serum TGF- $\beta 1(P<0.01), 10$ weeks PI and MMP-2 $(P<0.05), 10$ and 18 weeks PI, when compared to the corresponding PZQ treated group (Table 3).

Infection of mice with $S$. mansoni induced a significant increase $(P<0.001)$ in the hepatic content of HYP 10 and 18 weeks PI respectively, when compared to their corresponding uninfected untreated groups. Treatment with PZQ resulted in a significant reduction $(P<$ 0.001 ) in HYP content by $34.25 \%$ and $39.61 \%, 10$ and 18 weeks PI respectively, when compared to their corresponding infected untreated groups. In addition, treatment with silymarin showed significant reduction $(P<$ 0.05 ) by $19.06 \%$ and $17.02 \% 10$ and 18 weeks PI, respectively. Administration of PZQ with silymarin produced insignificant reduction in HYP content 10 and 18 weeks PI, when compared to their corresponding PZQ treated groups (Table 4).

\section{Immunohistochemical aspects}

The control, normal, uninfected mice were negative for TGF- $\beta 1$ and MMP-2 monoclonal antibodies. S. mansoni infected untreated mice showed positively TGF- $\beta 1$ and MMP-2 stained hepatocytes (cytoplasmic), fibroblast and inflammatory cells of granulomas (Figures 2 \&3a, b). Treatment with PZQ in the $7^{\text {th }}$ week PI significantly reduced the expression of TGF- $\beta 1$ (Figure $2 \mathrm{a} \& \mathrm{~b}$ ) and MMP-2 (Figure 3a \& b) by $(70.75 \%, 52.88 \% ; P<0.001$ ) and $(29.72 \% ; P<0.05,64.66 \% ; P<0.001)$ respectively, when compared with their corresponding infected untreated groups, 10 and 18 weeks PI respectively (Table 4). Treatment with silymarin in the $4^{\text {th }}$ and $12^{\text {th }}$ weeks PI significantly reduced $(P<0.001)$ the expression of TGF- $\beta 1$ (Figure 2a \& b) and MMP-2 (Figure 3a \& b) by $49.60 \%, 48.61 \%$ and $47.30 \%, 29.00 \%$, respectively, when compared with their corresponding infected untreated groups, 10 and 18 weeks PI, respectively. In groups treated with both $\mathrm{PZQ}$ and silymarin, the reduction in the expression of TGF- $\beta 1$ (Figure $2 \mathrm{a} \& \mathrm{~b}$ ) was significant and reached $84.13 \%$ and $67.09 \%(P<0.01)$ versus PZQ alone $(70.75 \%, 52.88 \%) 10$ and 18 weeks PI, respectively. Meanwhile, the reduction in the expression of MMP-2 (Figure 3a \& b) was $44.59 \%(P<0.05)$ and $70.80 \%(P>0.05)$ versus PZQ alone $(29.72 \%, 64.66 \%) 10$ and 18 weeks PI, respectively (Table 4 ).

\section{Recruitment of mast cells in liver tissue}

In toluidine blue-stained liver sections from the S.mansoni-infected group, mast cells were oval in shape with 
Table 3 Effect of silymarin with/without praziquantel on serum transforming growth factor- $\beta 1$ and matrix metalloproteinase-2, 10 and 18 weeks post infection of mice with S.mansoni

\begin{tabular}{|c|c|c|c|c|}
\hline \multirow[t]{2}{*}{ Animal groups } & \multicolumn{2}{|c|}{ Serum TGF- $\beta 1$ (ng/ml) } & \multicolumn{2}{|c|}{ Serum MMP-2 (ng/ml) } \\
\hline & 10 wks & 18 wks & 10 wks & 18 wks \\
\hline Uninfected (vehicle) & $7.80 \pm 0.69$ & $7.98 \pm 0.48$ & $150.40 \pm 18.17$ & $181.00 \pm 6.72$ \\
\hline Infected (Vehicle) & $\begin{array}{c}\text { †† } \\
19.98 \pm 2.37\end{array}$ & $\begin{array}{c}+\dagger \\
40.85 \pm 1.41\end{array}$ & $\begin{array}{c}+ \\
265.43 \pm 21.65\end{array}$ & $\begin{array}{c}t+\dagger \\
374.00 \pm 32.16\end{array}$ \\
\hline Infected+ PZQ & $\begin{array}{c}\text { 㧊 } \\
11.32 \pm 0.85 \\
(43.34 \%)\end{array}$ & 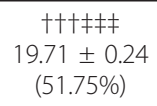 & $\begin{array}{c}\text { t† } \\
210.40 \pm 8.13 \\
(20.73 \%)\end{array}$ & $\begin{array}{c}\text { †十†キキ } \\
226.83 \pm 11.69 \\
(39.35 \%)\end{array}$ \\
\hline Infected + silymarin & $\begin{array}{c}+十+\neq \\
13.44 \pm 0.75 \\
(32.73 \%) \\
\end{array}$ & $\begin{array}{c}\text { †† } \\
36.84 \pm 1.44 \\
(9.82 \%) \\
\end{array}$ & $\begin{array}{c}\text { †े } \\
241.31 \pm 36.25 \\
(9.093 \%) \\
\end{array}$ & $\begin{array}{c}\text { †† } \\
283.80 \pm 42.20 \\
(24.12 \%) \\
\end{array}$ \\
\hline Infected + PZQ + silymarin & $\begin{array}{c}\neq \neq \neq \S \S \\
7.83 \pm 0.65 \\
(60.81 \%)\end{array}$ & 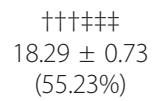 & $\begin{array}{c}\neq \neq \S \\
165.33 \pm 14.20 \\
(37.71 \%)\end{array}$ & $\begin{array}{c}\neq \neq \neq \S \\
187.60 \pm 11.57 \\
(49.84 \%)\end{array}$ \\
\hline
\end{tabular}

Data are presented as mean \pm SEM $(n=8$ in each group).

Mice were administered praziquantel (PZQ; $500 \mathrm{mg} / \mathrm{kg} /$ day for 2 days) in the $7^{\text {th }}$ week post infection (PI) and silymarin (750 mg/kg/day, 5 days/week for 6 weeks) at the $4^{\text {th }}$ and $12^{\text {th }}$ weeks PI for 6 weeks and were killed 10 and 18 weeks PI respectively. Numbers in parentheses indicate the percentage of reduction from infected (vehicle) group.

†† Significantly different from uninfected (vehicle) group at $P<0.01$ and $+\dagger \dagger$ at $P<0.001$. $\neq$ Significantly different from infected (vehicle) group at $P<0.05$, $\neq \neq$ at $P<0.01$ and $\neq \neq \neq$ at $P<0.001$. Significantly different from infected treated with PZQ group at $P<0.05$ and $\S \S$ at $P<0.01$.

metachromatic granules in portal areas and in the granuloma. At 10 and 18 weeks PI, the number of mast cells was $5.00 \pm 0.36$ and $3.83 \pm 0.48 / 10$ successive fields, respectively (Figure 4). However, in the infected PZQtreated group, the number of mast cells was significantly decreased $(P<0.001)$ by $66.60 \%$ and $60.84 \%, 10$ and 18 weeks PI respectively, compared with the infected untreated group. Also, in the infected silymarin-treated group, the number of mast cells was decreased significantly $(P<0.001)$ by $83.40 \%$ and $91.38 \% 10$ and 18 weeks PI, respectively. Meanwhile, in the infected group treated with both PZQ and silymarin, complete absence of mast cells was observed 10 and 18 weeks PI, respectively (Figure 5a, b).

\section{Discussion}

Although chemotherapy eliminates matured worms effectively and prevents the accumulation of schistosome

Table 4 Effect of silymarin with/without praziquantel on hepatic hydroxyproline content and immunohistochemical expression of transforming growth factor- $\beta 1$ and matrix metalloproteinase-2, 10 and 18 weeks post-infection of mice with S.mansoni

\begin{tabular}{|c|c|c|c|c|c|c|}
\hline \multirow[t]{3}{*}{ Animal groups } & \multicolumn{4}{|c|}{$\begin{array}{c}\text { Within } 10 \text { successive microscopic fields }(\times 400) / \text { section/animal } \\
(\text { Mean percentage +ve cells } \pm \text { SEM) }\end{array}$} & \multicolumn{2}{|c|}{$\begin{array}{l}\text { Hydroxyproline content } \\
(\mu \mathrm{g} / \mathrm{g} \text { liver })\end{array}$} \\
\hline & \multicolumn{2}{|c|}{ TGF- $\beta 1$} & \multicolumn{2}{|c|}{ MMP-2 } & \multirow[b]{2}{*}{10 wks } & \multirow[b]{2}{*}{18 wks } \\
\hline & 10 wks & 18 wks & 10 wks & 18 wks & & \\
\hline Uninfected(vehicle) & $0.0 \pm 0.0$ & $0.0 \pm 0.0$ & $0.0 \pm 0.0$ & $0.0 \pm 0.0$ & $789.45 \pm 50.61$ & $763.82 \pm 22.32$ \\
\hline Infected (Vehicle) & & & & & $\begin{array}{c}\text { t†† } \\
1495.88 \pm 91.85\end{array}$ & $\begin{array}{c}\text { †十† } \\
1961.96 \pm 80.97\end{array}$ \\
\hline Infected + PZQ & $\begin{array}{c}\text { 抹 } \\
14.80 \pm 0.37 \\
(70.75 \%)\end{array}$ & $\begin{array}{c}\text { 㧊 } \\
29.5 \pm 2.01 \\
(52.88 \%)\end{array}$ & $\begin{array}{c}\ddagger \\
26.0 \pm 1.62 \\
(29.72 \%)\end{array}$ & $\begin{array}{c}\text { 抹 } \\
17.67 \pm 1.82 \\
(64.66 \%)\end{array}$ & 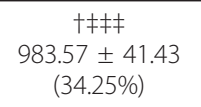 & $\begin{array}{c}\text { †十ナキキキ } \\
1184.84 \pm 77.27 \\
(39.61 \%)\end{array}$ \\
\hline Infected + silymarin & $\begin{array}{c}\text { 抹 } \\
25.50 \pm 2.81 \\
(49.60 \%)\end{array}$ & $\begin{array}{c}\text { 抹 } \\
32.17 \pm 3.30 \\
(48.61 \%)\end{array}$ & $\begin{array}{c}\text { 㧊 } \\
19.5 \pm 1.33 \\
(47.30 \%)\end{array}$ & 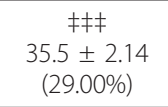 & $\begin{array}{c}\text { †十† } \\
1210.71 \pm 89.85 \\
(19.06 \%)\end{array}$ & $\begin{array}{c}\text { t†キ } \\
1628.01 \pm 111.92 \\
(17.02 \%)\end{array}$ \\
\hline Infected + PZQ + silymarin & $\begin{array}{c}\neq \neq \neq \S \S \\
8.03 \pm 1.69 \\
(84.13 \%)\end{array}$ & $\begin{array}{c}\neq \neq \neq \S \S \\
20.60 \pm 0.60 \\
(67.09 \%)\end{array}$ & $\begin{array}{c}\neq \neq \neq \S \\
20.5 \pm 1.14 \\
(44.59 \%)\end{array}$ & $\begin{array}{c}\text { 抹 } \\
14.60 \pm 1.72 \\
(70.80 \%)\end{array}$ & 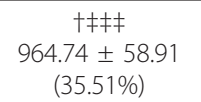 & $\begin{array}{c}\text { †††キキキ } \\
1043.50 \pm 58.45 \\
(46.81 \%)\end{array}$ \\
\hline
\end{tabular}

Data are presented as mean \pm SEM ( $\mathrm{n}=8$ in each group).

Mice were administered praziquantel (PZQ; $500 \mathrm{mg} / \mathrm{kg} /$ day for 2 days) in the $7^{\text {th }}$ week post infection (PI) and silymarin (750 mg/kg/day, 5 days/week for 6 weeks) at the $4^{\text {th }}$ and $12^{\text {th }}$ weeks PI for 6 weeks and were killed 10 and 18 weeks PI respectively. Numbers in parentheses indicate the percentage of reduction from infected (vehicle) group. TGF- $\beta 1$, transforming growth factor $\beta 1$; MMP-2, matrix metalloproteinase- 2 .

† Significantly different from uninfected (vehicle) group at $P<0.05$ and $+\dagger \dagger$ at $P<0.001$. ₹ Significantly different from infected (vehicle) group at $P<0.05$ and

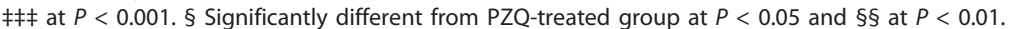




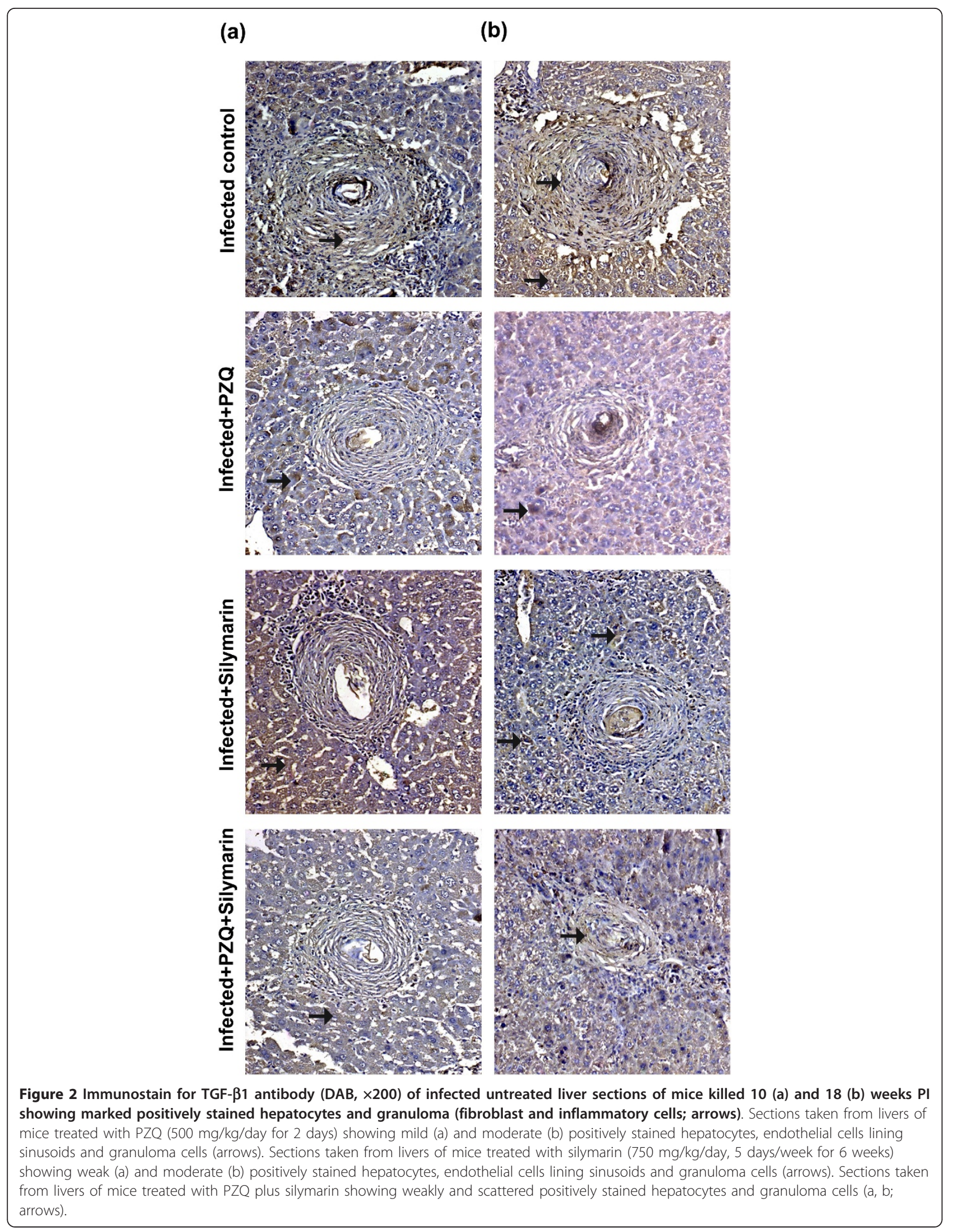




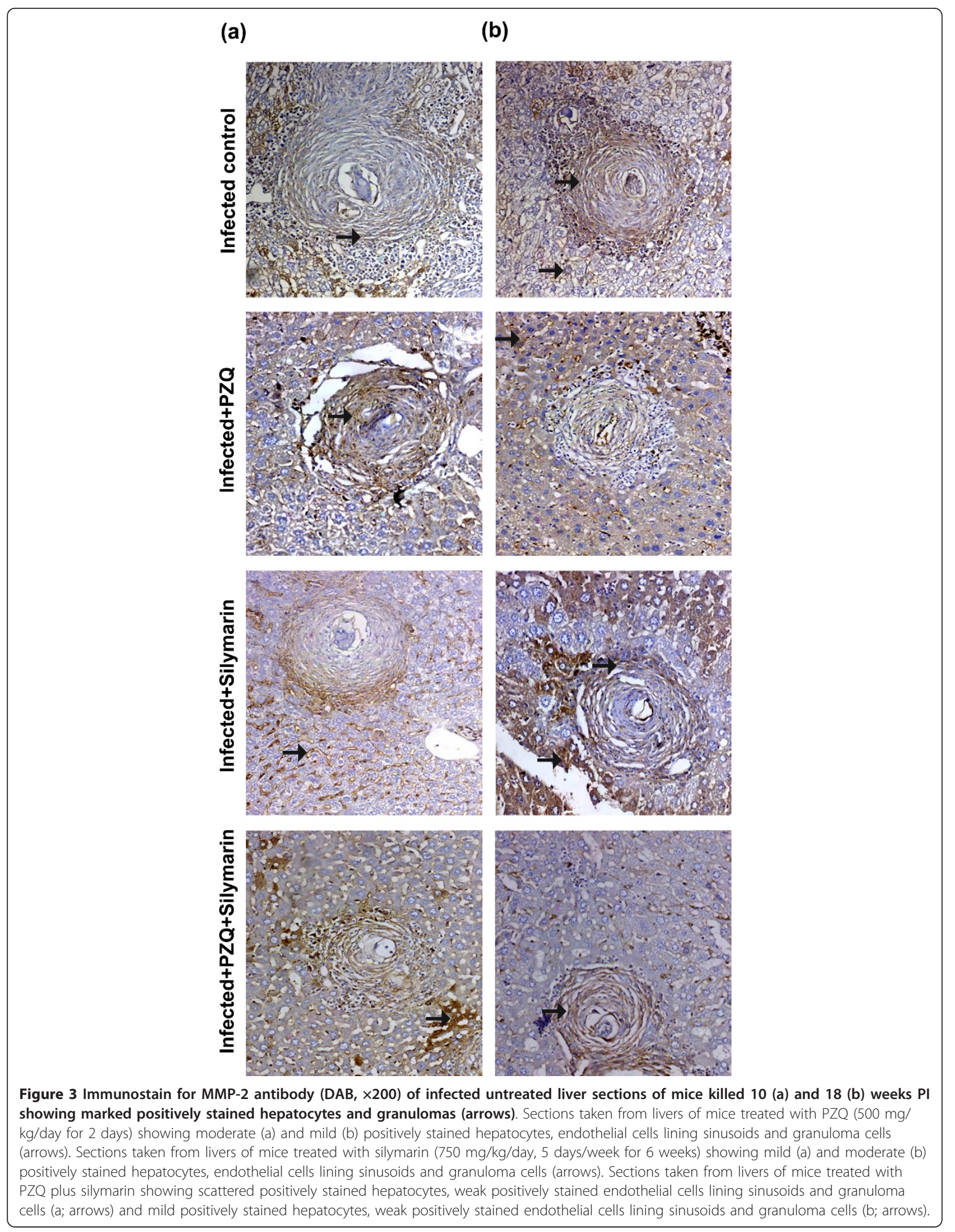




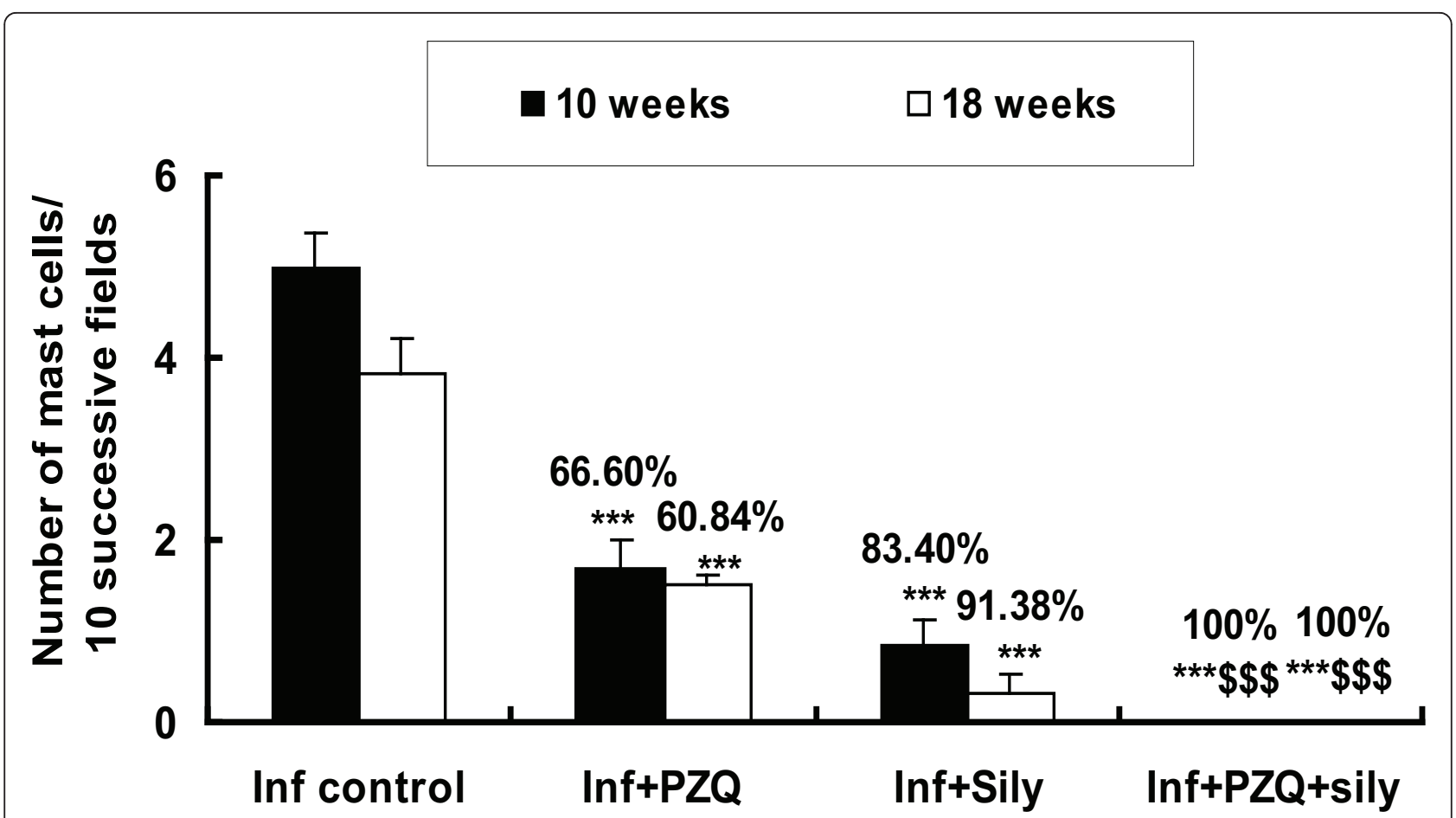

Figure 4 Effect of silymarin with/without praziquantel on the total number of mast cells/10 successive fields/section, 10 and 18 weeks post-infection of mice with S. mansoni. Numbers in parentheses indicate the percentage of reduction from infected (vehicle) group. ${ }^{* * *}$ Significantly different from infected (vehicle) group at $P<0.001$. $\$ \$$, Significantly different from infected-PZQ treated group at $P<0.001$.

eggs, less effective drugs are directed to reversing the existing hepatic fibrosis, especially at the chronic and advanced stages of schistosomiasis. Therefore, treatment targeting hepatic fibrosis of schistosomiasis remains a challenging proposition [31]. Because the mouse model has a similar course to human schistosomiasis [32], we, thus, established the mouse schistosomiasis model through Schistosoma mansoni cercariae infection, and then treated them with either silymarin alone or plus praziquantel to diminish liver fibrosis in the current study. In this study, all mice received $S$. mansoni infection in addition to the presence of hepatic granulomas around deposited schistosome eggs affecting hepatocellular function. The observed elevation in ALT reflects either acute active or chronic liver damage [33], and hypoalbuminemia in chronic infection occurs simultaneously with the increase in collagen deposition. This could be associated with malabsorption due to damaged intestinal mucosa resulting from the extrusion of large numbers of eggs, or could be due to decreased synthesis which may result from parasitic injury to hepatic cells [34]. In addition, a significant depletion of GSH, which constitutes the first line of defence against free radicals and is a critical determinant of tissue susceptibility to oxidative damage, was observed. In the present study, hydroxyproline was chosen because it is a sensitive marker that increases significantly during liver fibrosis. The increase in this amino acid reflects an increase in the de novo synthesis of liver collagen and an increase in the amount of hydroxyproline [35]. Here, there was a linked increase in serum MMP-2, TGF- $\beta 1$ and the HYP content in both acute and chronic infections. This could be due to the activated HSCs during the acute stage of fibrosis producing more MMPs to counteract the overproduction of collagen-I, which was dominant from the onset of the fibrotic response and peaked at the chronic phase of infection [36]. Singh et al. [37] reported that there was a strong rise in collagen I and III expression in the liver seven weeks post infection indicating that induction of collagen production was associated with the early development of the granulomatous response. In addition, MMP- 2 and TGF- $\beta 1$ levels continued to rise reaching the highest level at the $18^{\text {th }}$ week post infection. Loebermann et al. [38] reported that the expression of MMP-2 correlated well with the onset and progression of fibrosis.

In the current study, treatment of $S$. mansoni-infected mice with silymarin alone at the $4^{\text {th }}$ and $12^{\text {th }}$ weeks PI resulted in remarkable worm and egg reduction accompanied with a partial increase in the percentage of dead eggs 10 and 18 weeks PI. This was associated with healing of hepatic granulomatous lesions as evidenced 


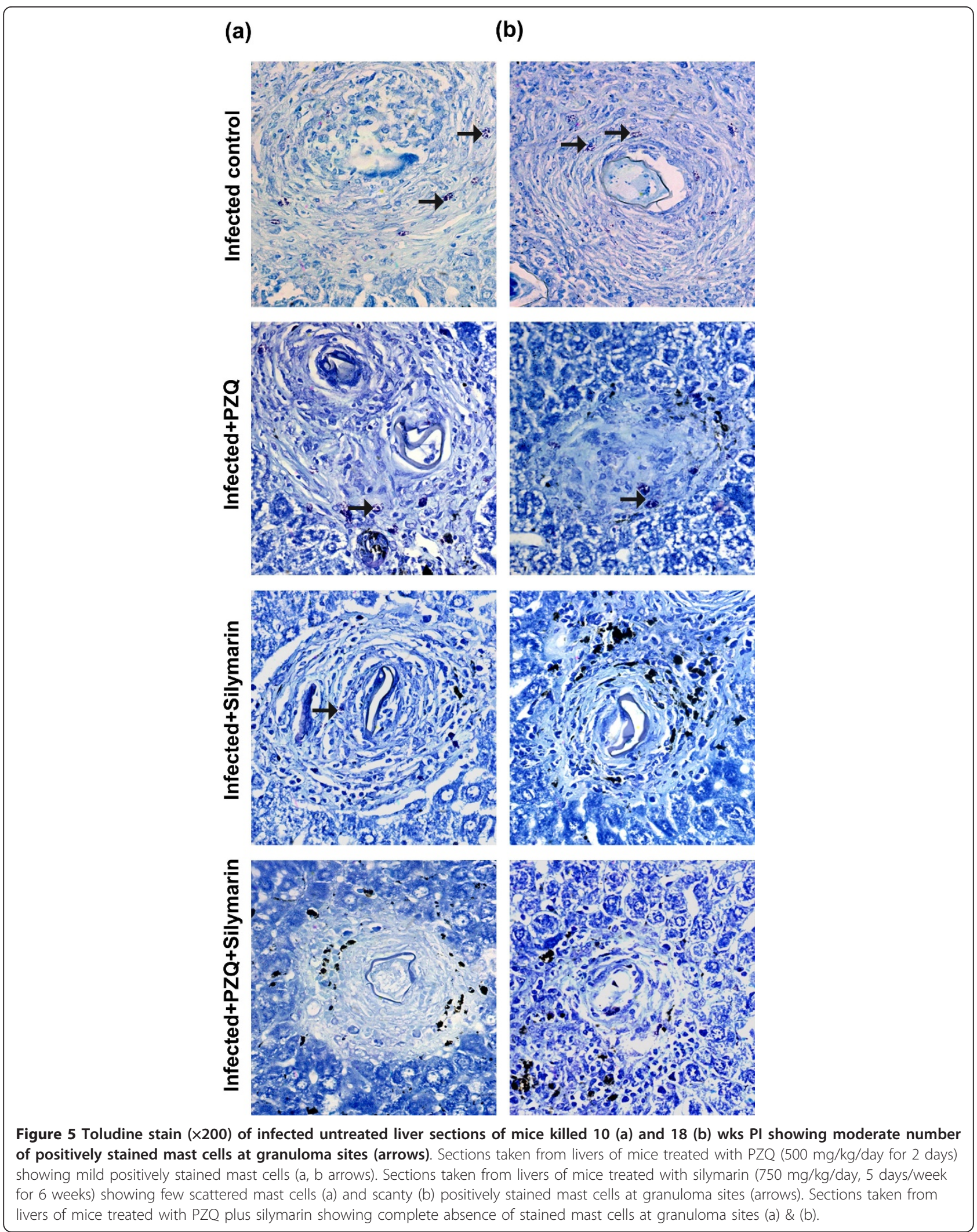


histopathologically with reduction of granuloma size, more granuloma circumscription, more ova degeneration and fewer inflammatory cells. This may be attributed to the antioxidative properties of silymarin [39], therefore, it is possible that silymarin eliminates the products of oxidative reactions and assists in the immunemediated destruction of worms and eggs. Also, treatment with silymarin, whether in acute or chronic infection, significantly reduced the hepatic HYP content, tissue expression of TGF- $\beta 1$ and MMP- 2 and the number of mast cells. This is consistent with previous studies, which showed that administration of silymarin reduced the hepatic collagen content in diethylnitrosamine [40] and $\mathrm{CCl}_{4}$ administered rats [41], and exerts its anti-fibrotic properties by reducing TGF- $\beta$ induced de novo synthesis of collagen type I [42]. Fuchs et al. [15] reported that prolonged treatment with silymarin resulted in its accumulation in HSCs and down regulated TGF- $\beta 1$ expression; since this growth factor has the ability to induce its own production, silymarin broke the so-called fibrogenesis loop, or the self-perpetuation of hepatic fibrosis. In this study, the number of mast cells in portal areas and granulomas decreased significantly in the silymarin-treated group compared to those of the infected group. Mast cells secrete various mediators, which promote fibroblast growth, stimulate production of the extracellular matrix by fibroblasts of hepatic stellate cells, and produce components of the extramedullary matrix themselves [43]. However, it is unclear whether they play a central role in its development. Thus, silymarin has been histopathologically shown to have a significant anti-inflammatory effect on hepatic tissue, including mast cell stabilization.

In the current study, silymarin alone significantly reduced the elevated ALT and restored the depletion of GSH with no alteration in serum albumin level 10 and 18 weeks PI. Silymarin restored the elevated level of serum ALT in $\mathrm{CCl}_{4}$ intoxicated rats [44] and in diethylnitrosamine administered rats [45] by preventing liver damage through maintaining the integrity of the plasma membrane, thereby suppressing the leakage of enzymes. The increase in the hepatic GSH content may be attributed to the well established antioxidant actions of silymarin [39], which was able to dramatically reduce the generation of intracellular ROS in response to different pro-oxidant stimuli [42]. Furthermore, silymarin is capable of protecting liver cells directly by stabilizing the membrane permeability through inhibiting lipid peroxidation and preventing liver glutathione depletion, thus offering the synergistic benefit of sparing liver cells from destruction [46].

Reversal of schistosome-induced pathology after treatment with PZQ has been previously described [47]. In contrast to that, our findings show that PZQ alone seemed to be effective in reducing hepatic fibrosis as shown by a clear reduction in the serum levels and tissue expression of TGF- $\beta 1$ and MMP-2, the number of mast cells and hepatic HYP content at 10 and 18 weeks PI. This was accompanied by a significant reduction in ALT with significant restoration of albumin and GSH. The main explanations for these results are presumed to be a removal of schistosomal worms, and subsequent reduction of egg deposition and granuloma size. Researchers showed that patients in Ethiopia and Uganda had improvement or resolution of schistosomal periportal thickening/fibrosis after parasitologic cure with PZQ [48,49]. Singh et al. [50] reported that with elimination of eggs and subsidence of the inflammatory response, collagen gene expression was minimal and that collagen and MMP-2 gene expression diminished in a linked fashion. The authors added that, the weakening of the inflammatory signals, may lead to a decrease in the activation of HSCs and diminished the production of IL-13 by monocytes and macrophages, which in turn reduced the stimulation of TGF- $\beta 1$. In addition, in the face of decreased collagen production and deposition, expression of MMP-2 genes also decreased because the bulk of the deposited fibrous tissue had been desorbed and consequently the curtailed gene expression of MMP-2 is appropriate [50]. In a recent study by Liang et al. [51] on the anti-fibrotic effects of PZQ in mice with both chronic and advanced schistosomiasis as well as in $\mathrm{CCl}_{4}$ induced liver fibrosis mice, they mentioned that the significant amelioration of hepatic fibrosis by praziquantel treatment validates it as a promising antifibrosis drug and offers the potential for new chemotherapy for hepatic fibrosis resulting from schistosomiasis.

Administration of silymarin in addition to PZQ also showed complete eradication of worms, no viable eggs with reduction in the hepatic tissue egg load and more healing of hepatic granulomatous lesions revealing that the use of silymarin along with PZQ did not interfere with, or affect, the antischistosomal activity of PZQ. The highest reduction observed in TGF- $\beta 1$, MMP- 2 and mast cells was in the group treated with PZQ plus silymarin. In addition, the improvement of liver function and histopathology whether in acute or chronic infections may be due to blocking liver fibrosis through killing parasites and complete eradication of eggs and their toxins by PZQ to alleviate liver inflammation, and to the anti-inflammatory, anti-fibrotic actions, in addition to the antioxidative properties of silymarin. Although the hepatoprotective properties of silymarin have been reported from both in vitro and in vivo studies, its mechanism of action still has not been established [52]. Velebný et al. [53] showed that combined treatment with PZQ and silymarin in mice infected with 
Mesocestoides vogae (Cestoda) tetrathyridia was able to ameliorate or suppress fibrogenesis in the liver, protect liver cells from oxidative damage and, possibly, stimulate regeneration of the parenchyma. Interestingly, the reduction in HYP content in the group treated with silymarin plus PZQ did not reach a significant level compared with the PZQ treated group. Silymarin is thought to be dose-dependent and studies vary considerably in duration without agreement on the minimum duration needed to see the effect $[54,55]$. Therefore, further studies are clearly needed to investigate the efficacy of higher doses and a longer duration of treatment with silymarin in this model of liver fibrosis.

In conclusion, silymarin has partially toxic effects on worms and eggs. Furthermore, the anti-fibrotic and antiinflammatory effects of silymarin/PZQ alone were observed in the acute and chronic fibrogenesis induced by $S$. mansoni infection. This was evident in diminishing hepatic content of HYP, serum levels and hepatic expression of TGF- $\beta 1$ and MMP- 2 and the number of mast cells. These effects were more obvious in most parameters studied, when silymarin was used with the removal of the causative agent by PZQ. Accordingly, our results point to silymarin as a convenient and promising therapeutic agent in the treatment of schistosomal liver fibrosis. Further studies on mechanisms of action of silymarin and praziquantel during schistosomal liver fibrosis or other chronic liver diseases may shed some light on developing therapeutic methods in clinical practice.

\section{Acknowledgements}

This work was supported by the internal research project 82/A for basic and applied research, a grant from Theodor Bilharz Research Institute.

\section{Author details}

'Department of Pharmacology, Theodor Bilharz Research Institute, Warrak ElHadar, Imbaba, P.O Box 30, Giza 12411, Egypt. ²Department of Pathology, Theodor Bilharz Research Institute, Warrak El-Hadar, Imbaba, P.O Box 30, Giza 12411, Egypt. ${ }^{3}$ Department of Pharmacology, Faculty of Pharmacy, Cairo University, Kasr El-Aini St., Cairo 11562, Egypt.

\section{Authors' contributions}

NME, FAE and AAA conceived and designed the research; NME, WHE performed the animal experiments, parasitological and biochemical examinations; $\mathrm{OAH}$ and $\mathrm{AAB}$ performed the histological and immunohistochemical procedures; NME, WHE and OAH analyzed the data; NME interpreted data and wrote the paper. All authors read and approved the final submitted and revised versions of the manuscript.

\section{Competing interests}

The authors declare that they have no competing interests.

Received: 19 October 2011 Accepted: 11 January 2012 Published: 11 January 2012

\section{References}

1. Burke ML, McManus DP, Ramm GA, Duke M, Li Y, Jones MK, Gobert GN: Temporal expression of chemokines dictates the hepatic inflammatory infiltrate in a murine model of schistosomiasis. PLOS Negl Trop Dis 2010, 4:e598.
2. Cheever AW, Jankovic D, Yap GS, Kullberg MC, Sher A, Wynn TA: Role of cytokines in the formation and downregulation of hepatic circumoval granulomas and hepatic fibrosis in Schistosoma mansoni infected mice. Mem Inst Oswaldo Cruz 1998, 93:25-32.

3. Kresina TF, He Q, Degli Esposti S, Zern MA: Gene expression of transforming growth factor 1 and extracellular matrix proteins in murine Schistosoma mansoni infection. Gastroenterology 1994, 107:773-780.

4. Du WD, Zhang YE, Zhai WR, Zhou XM: Dynamic changes of type I, II and IV collagen synthesis and distribution of collagen-producing cells in carbon tetrachloride induced rat liver fibrosis. World J Gastroenterol 1999, 5:397-403.

5. Wang YF, Li QF, Wang H, Mao Q, Wu CQ: Effects of vitamin E on experimental hepatic fibrosis in rats. World J Gastroenterol 1998, 4:157.

6. Sugihara A, Tsujimura T, Fujita Y, Nakata Y, Terada N: Evaluation of role of mast cells in the development of liver fibrosis using mast cell-deficient rats and mice. J Hepatol 1999, 30:859-867.

7. Jones SE, Kelly DJ, Cox AJ, Zhang Y, Gow RM, Gilbert RE: Mast cell infiltration and chemokine expression in progressive renal disease. Kidney Int 2003, 64:906-913.

8. Jeong $D$, Lee $G$, Jeong W, Do S, Yang H, Yuan D, Park H, Kim K, Jeong K: Alterations of mast cells and TGF- $\beta 1$ on the silymarin treatment for $\mathrm{CCl}_{4}$ induced hepatic fibrosis. World J Gastroenterol 2005, 11:1141-1148.

9. Takahara T, Furui K, Yata Y, Jin B, Zhang LP, Nambu S, Sato H, Seiki M, Watanabe A: Dual expression of matrix metalloproteinase-2 and membrane-type-1-matrix metalloproteinase in fibrotic human livers. Hepatology 1997, 26:1521-1529.

10. Albanis E, Safadi R, Friedman S: Treatment of hepatic fibrosis: almost there. Curr Gastroenterol Rep 2003, 5:48-56.

11. Fenwick A, Savioli L, Engels D, Robert Bergquist N, Todd MH: Drugs for the control of parasitic diseases: current status and development in schistosomiasis. Trends Parasitol 2003, 19:509-515.

12. Homeida MA, el Tom I, Nash T, Bennett JL: Association of the therapeutic activity of praziquantel with the reversal of Symmers' fibrosis induced by Schistosoma mansoni. Am J Trop Med Hyg 1991, 45:360-365.

13. Valenzuela A, Garrido A: Biochemical bases of the pharmacological action of the flavonoid silymarin and of its structural isomer silibinin. Biol Res 1994, 27:105-112.

14. Down WH, Chasseaud LF, Grundy RK: Effect of silybin on the hepatic microsomal drug metabolizing enzyme system in the rat. Arzneim Forsch/ Drug Res 1974, 24:1986-1988.

15. Fuchs EC, Weyhenmeyer R, Weiner OH: Effects of silibinin and of a synthetic analogue on isolated rat hepatic stellate cells and myofibroblasts. Arzneim Forsch/Drug Res 1997, 47:1383-1387.

16. Mata-Santos HA, Lino FG, Rocha CC, Paiva CN, Castelo Branco MT, Pyrrho Ados S: Silymarin treatment reduces granuloma and hepatic fibrosis in experimental schistosomiasis. Parasitol Res 2010, 107:1429-1434.

17. He Q, Kim J, Sharma RP: Silymarin protects against liver damage in BALB/ C mice exposed to Fumonisin B1 despite increasing accumulation of free sphingoid bases. Toxicol Sci 2004, 80:335-342.

18. Gonnert R, Andrews P: Praziquantel, a new broad-spectrum antischistosomal agent. Z Parasitenkd 1977, 52:129-150.

19. Liang $Y S$, John Bl, Boyd DA: Laboratory cultivation of schistosome vector snails and maintenance of schistosome life cycles. Proceeding of the 1st Sino-American Symposium 1987, 1:34-48.

20. Duvall RH, De Witt WB: An improved perfusion technique for recovering adult schistosomes from laboratory animals. Am J Trop Med Hyg 1967, 16:483-486.

21. Cheever AW: Conditions affecting the accuracy of potassium hydroxide digestion techniques for counting Schistosoma mansoni eggs in tissues. Bull World Health Organ 1968, 39:328-331.

22. Pellegrino J, Oliveira CA, Faria J, Cunha AS: New approach to the screening of drugs in experimental schistosomiasis mansoni in mice. Am J Trop Med Hyg 1962, 11:201-215.

23. Von Lichtenberg FC: Host response to eggs of Schistosoma mansoni. I. Granuloma formation in the sensitized laboratory mouse. Am J Pathol 1962, 41:711-731.

24. Ellman G: Tissue sulfhydryl groups. Arch Biochem Biophys 1959, 88:70-77.

25. Woessner JF: The determination of hydroxyproline in tissue and protein samples containing small proportions of this amino acid. Arch Biochem Biophys 1961, 93:440-447. 
26. Hsu SM, Raine L: Protein A, avidin and biotin in immunohistochemistry. J Histochem Cytochem 1981, 29:1349-1353.

27. Kim CK, Lim JH, Lee WJ: Detection of hepatocellular carcinomas and dysplastic nodules in cirrhotic liver: accuracy of ultrasonography in transplant patients. J Ultrasound Med 2001, 20:99-104.

28. Kanayama H, Yokota K, Kurokawa Y, Murakami Y, Nishitani M, Kagawa S: Prognostic values of matrix metalloproteinase-2 and tissue inhibitor of metalloproteinase-2 expression in bladder cancer. Cancer 1998, 82:1359-1366.

29. Churukian CJ, Schenk EA: A toluidine blue method for demonstrating mast cells. J Histopathol 1981, 4:85-86.

30. Kamel R, Dahiya P, Palaskar S, Shetty VP: Comparative analysis of mast cell count in normal oral mouse and oral pyogenic granuloma. J Clin Exp Dent 2011, 3:e1-4.

31. Andrade ZA: Schistosomiasis and hepatic fibrosis regression. Acta Tropica 2008, 108:79-82.

32. Abdul-Ghani RA, Hassan AA: Murine schistosomiasis as a model for human schistosomiasis mansoni: similarities and discrepancies. Parasitol Res 2010, 107:1-8.

33. Naik SR, Panda VS: Antioxidant and hepatoprotective effects of Ginkgo biloba phytosomes in carbon tetrachloride-induced liver injury in rodents. Liver Int 2007, 27:393-399.

34. Oliveira SA, Souza BS, Guimaraes-Ferreira CA, Barreto ES, Souza SC, Freitas LA, Ribeiro-Dos-Santos R, Soares MB: Therapy with bone marrow cells reduces liver alterations in mice chronically infected by Schistosoma mansoni. Braz J Med Biol Res 2009, 42:812-815.

35. Ala-kokko L, Stenback F, Ryhanen L: Preventive effect of malotilate on carbon tetrachloride-induced liver damage and collagen accumulation in the rat. Biochem J 1987, 246:503-509.

36. El-Meneza S, Olds GR, Kresina TF, Mahmoud AAF: Dynamics of hepatic connective tissue matrix constituents during murine Schistosoma mansoni infection. Hepatology 1989, 9:50-56.

37. Singh KP, Gerard HC, Hudson AP, Boros DL: Dynamics of collagen, MMP and TIMP gene expression during the granulomatous, fibrotic process induced by Schistosoma mansoni eggs. Ann Trop Med Parasitol 2004, 98:581-593.

38. Loebermann M, Sombetzki M, Langner C, Fuchsbichler A, Gumhold J,

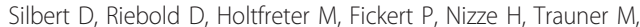
Reisinger EC: Imbalance of pro- and antifibrogenic genes and bile duct injury in murine Schistosoma mansoni infection-induced liver fibrosis. Trop Med Int Health 2009, 14:1418-1425.

39. Gazák R, Walterová D, Kren V: Silybin and silymarin-new and emerging applications in medicine. Curr Med Chem 2007, 14:315-338.

40. Zhao XY, Wang BE, Wang TL, Li XM: Inhibitory effects of silymarin on hepatic fibrosis induced by dimethylnitrosamine: experiment with rats. Zhonghua Yi Xue Za Zhi 2006, 86:2563-2566.

41. Zhao $X Y$, Zeng $X$, Li XM, Wang TL, Wang BE: Pirfenidone inhibits carbon tetrachloride- and albumin complex-induced liver fibrosis in rodents by preventing activation of hepatic stellate Cells. Clin Exp Pharmacol Physiol 2009, 36:963-968.

42. Trappoliere M, Caligiuri A, Schmid M, Bertolani C, Failli P, Vizzutti F, Novo E, di Manzano C, Marra F, Loguercio C, Pinzani M: Silybin, a component of sylimarin, exerts anti-inflammatory and anti-fibrogenic effects on human hepatic stellate cells. J Hepatol 2009, 50:1102-1111.

43. Weber S, Kruger-Krasagakes S, Grabbe J, Zuberbier T, Czarnetzki BM: Mast cells. Int J Dermatol 1995, 34:1-10.

44. Cho YK, Yun JW, Park JH, Kim HJ, Park DI, Sohn Cl, Jeon WK, Kim Bl, Jin W, Kwon YH, Shin MK, Yoo TM, Kang JH, Park CS: Deleterious effects of silymarin on the expression of genes controlling endothelial nitric oxide synthase activity in carbon tetrachloride-treated rat livers. Life Sci 2009, 85:281-290.

45. Pradeep K, Mohan CV, Gobianand K, Karthikeyan S: Silymarin modulates the oxidant-antioxidant imbalance during diethylnitrosamine induced oxidative stress in rats. Eur J Pharmacol 2007, 560:110-116.

46. Kiruthiga PV, Shafreen RB, Pandian SK, Devi KP: Silymarin protection against major reactive oxygen species released by environmental toxins: exogenous $\mathrm{H} 2 \mathrm{O} 2$ exposure in erythrocytes. Basic Clin Pharmacol Toxicol 2007, 100:414-419.

47. Chen MG: Use of praziquantel for clinical treatment and morbidity control of schistosomiasis japonica in China: a review of 30 years' experience. Acta Tropica 2005, 96:168-176.
48. Berhe N, Myrvang B, Gundersen SG: Reversibility of schistosomal periportal thickening/fibrosis after praziquantel therapy: a twenty-six month follow-up study in Ethiopia. Am J Trop Med Hyg 2008, 78:228-234

49. Frenzel K, Grigull L, Odongo-Aginya E, Ndugwa CM, Loroni-Lakwo T, Schweigmann U, Vester U, Spannbrucker N, Doehring E: Evidence for a long-term effect of a single dose of praziquantel on Schistosoma mansoni-induced hepatosplenic lesions in northern Uganda. Am J Trop Med Hyg 1999, 60:927-931.

50. Singh KP, Gerard HC, Hudson AP, Boros DL: Expression of matrix metalloproteinases and their inhibitors during the resorption of schistosome egg-induced fibrosis in praziquantel-treated mice. Immunology 2004, 111:343-352.

51. Liang $Y$, Luo J, Yuan Q, Zheng D, Liu Y, Shi L, Chen A, Ren Y, Sun K, Sun Y, Wang $Y$, Zhang Z: New insight into the antifibrotic effects of praziquantel on mice in infection with Schistosoma japonicum. PLOS One 2011, 6:e20247.

52. Song Z, Deaciuc I, Song M, Lee DY, Liu Y, Ji X, Mc Clain C: Silymarin protects against acute ethanol-induced hepatotoxicity in mice. Alcohol Clin Exp Res 2006, 30:407-413.

53. Velebný S, Hrckova G, Kogan G: Impact of treatment with praziquantel, silymarin and/or beta-glucan on pathophysiological markers of liver damage and fibrosis in mice infected with Mesocestoides vogae (Cestoda) tetrathyridia. J Helminthol 2008, 82:211-219.

54. Wilasrusmee C, Kittur S, Shah G, Siddiqui J, Bruch D, Wilasrusmee S, Kittur DS: Immunostimulatory effect of Silybum marianum (milk thistle) extract. Med Sci Monit 2002, 8:BR439-443.

55. Jacobs BP, Dennehy C, Ramirez G, Sapp J, Lawrence VA: Milk thistle for the treatment of liver disease: A systematic review and meta-analysis. Am J Med 2002, 113:506-515.

doi:10.1186/1756-3305-5-9

Cite this article as: El-Lakkany et al:: Anti-inflammatory/anti-fibrotic effects of the hepatoprotective silymarin and the schistosomicide praziquantel against Schistosoma mansoni-induced liver fibrosis. Parasites \& Vectors 2012 5:9.

\section{Submit your next manuscript to BioMed Central and take full advantage of:}

- Convenient online submission

- Thorough peer review

- No space constraints or color figure charges

- Immediate publication on acceptance

- Inclusion in PubMed, CAS, Scopus and Google Scholar

- Research which is freely available for redistribution

Submit your manuscript at www.biomedcentral.com/submit
C Biomed Central 